\title{
The Exploration of a New mode of Internet plus Tourism
}

\author{
Xueqiu Zhuang \\ Institute of tourism \\ Hainan Institute of Science \& Technology \\ Haikou,China \\ 274355812@qq.com
}

\author{
Laiyan Yun \\ Institute of tourism \\ Hainan Institute of Science \& Technology \\ Haikou,China \\ yunlaiyan@163.com
}

\begin{abstract}
After decades of development, China's tourism industry has made brilliant achievements, entering the period of mass tourism characterized by independent tourism and self-help tourism. Along with the vigorous development of Chinese tourism industry, the application and strong growth of the Internet technology, the online travel service market is becoming the most vital area which grows very fast. This paper aims to analyze the drawbacks of the existing sales model in tourism industry and a new mode of application in internet plus tourism in the process of tourism industry in the future, based on the main line of tourism industry which is the most vital area in the third industry at the background of internet distinguishing to the traditional tourism pattern characterized by E-Commercialization.
\end{abstract}

Keywords-internet;tourism; Mobile;One-stop; online

\section{INTRODUCTION}

Since the Reform and Opening of our country, not only the fields of social economy and technology have developed rapidly, but also the field of the industry development are in line with international standards. With the rapid popularization of mobile Internet in various fields of our country, theInternet has been gradually changing the consumption patterns and traditional purchasing habits of people.Especially for he new generation groups born afte 80 s and 90 s, the online consumption has become an important part of their lives, and has gradually formed a new consumer culture.In the background of the rapid development of network consumption, tourism consumption as a part of the main body of it, self-help travel is also beginning to emerge and rapidly spread between enterprises and consumers of the travel .But, at present, the services that our country tourism network marketing provides still are the three items --airline ticket[1], hotel and tour, which is not innovative changes and obvious advantages compared with the services that the traditional travel agency, ticket sales and hotel reservation center provide.So, it is necessary to use the mobile Internet network to provide consumers with a better path for their choice, so as to achieve the tourists' experience, and make the tourists enjoy a greater time in the travel.

\section{THE STATE OF DOMESTIC TOURISM DEVELOPMENT}

At present Our country's tourism industry is mainly composed of travel agents, travel suppliers, and visitors. Tourism is divided into two way, individual travel and tourism travel agency group,through using the traditional way of tourist, many tourism work is finished by human labor-intensive. Its characteristics are:

\section{A. Traditional marketing method of tourism is the main marketing means}

Namely through newspapers, televisions, magazines and the other media advertising ways to approve the enterprise and develop the products according to the vision or intention of the technicians themselves. However, this methods not only lead to an unsatisfactory effect but high cost[2].

B. The major contact way of tourism are adopted by telephone, telegraph and fax which takes a lot of time and high cost.

Backward means and methods of tourism management seriously restrict the development of tourism in our country in the future. Nowadays economic globalization and the network has become an irreversible trend.And construction and technology revolution of the information are gradually making the Capital Economics into information economy[3], knowledge economy and they will quickly change the traditional way of trading, which means not only tourist economy suffered accordingly but also won the development opportunity at the same time. Actually tourism economy can totally adapt to the world and evolve toward informationbased path with its own characteristics and development requirements. It is the inevitable trend of tourism industry in China[4].

\section{THE PROSPECT OF DOMESTIC TOURISM}

\section{A. The tourism industry has already formed the scale}

The tourism industry has already formed the scale and its backbone role is more strengthened.Therefore the tourism industry in quality and quantity will keep sustainable. Besides the tourism resources will develop in multiple perspectives but with full of opportunities and challenges [5]. 
The domestic tourism market, inbound tourism, outbound tourism market develop very well. It show an upward trend of the number of tourists, total income, travel consumption per capita spending, which makes tourism in china rank first in the world. That's why the world tourism organization has given a very high expectation to ours and predicts that by 2015, china will be ranked the first in the world tourism destination and ranked fourth among the world tourist source countries. While the increasing rate of china's tourism industry is also significantly faster than that of other major countries[6].

\section{B. Pillar of tourism industry reflected}

Tdue to increasingly prominent role of the tourism industry in our country, its development has already been included in the China's national economic and social development plan. The National Tourism Administration formulated Chinese tourism development "Nine Five" plan and long-term goals for the year 2010 and China tourism development program "fifteen" respectively in 1995 and 2000. Each province, autonomous region knew from their advantages of tourism resources and took tourism industry as the dominant industry of local economy and industry[7], of which more than 10 provinces will took tourism industry as the pillar industry, 7 provinces took it as an important and leading industry, the 6 provinces took it as the leading industries of third industry.

\section{Booming development of tourism}

Since the reform and opening up, the rapid development of China's tourism industry continues to expand the scale , the industrial system became more and more mature and the three major tourism markets were blooming completely. With enormous pressure on the global economic crisis and all kinds of natural disasters in China in 2014, the number of domestic tourists still reached to 1.902 billion, domestic tourism earns 102 million yuan. The number of inbound tourists achieved 126 million passengers and got foreign exchange income of $\$ 39.7$ billion dollars.And 47.66 million tourists went outbound and reached 1.29 trillion yuan of the total tourism revenue. In the meantime, along with the State Council on accelerating the development of the tourism industry opinions issued, the development of the tourism industry has brought into the national strategic system. In the attention and promote of the party committees and governments at all levels, they decide to cultivate tourism as a strategic pillar industry of our national economy and the modern service industry that people will be more satisfied with,which forecasts the Chinese tourism industry will usher in a new round of development climax [8].

\section{The strong growth of the Internet}

China Internet Network Information Center released statistics report of the thirty-sixth China Internet Development displaying that up to June 2015, China's Internet citizens reached 668 million, a total of 18,940,000 new users in half a year. The Internet penetration rate is $48.8 \%$ which increased 0.9 percentage compared to the end of 2014, and still maintained a momentum of rapid growth of
Internet users in China. Three indicators still ranked first in the world, including the scale of China's Internet users, broadband Internet users, the national top-level domain registrations. Chinese mobile phone users reached 594 million, an increase of $36,790,000$ people compared to December 2014. Mobile phone users in the Internet population proportion increased from $85.8 \%$ in December 2014 to $88.9 \%$. Chinese online travel booking users reached million, an increase of this year is also expected to reach million. The rapid growth of online travel consumer groups has become service business model of the online travel and evolution of the absolute market subject.

Ten thousand people

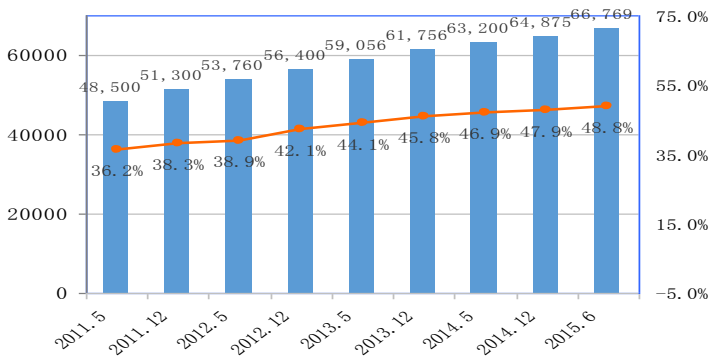

Wumber of internet users - - internet penetration

Figure 1. scale of Chinese netizens and penetration

Source: China Internet network information center

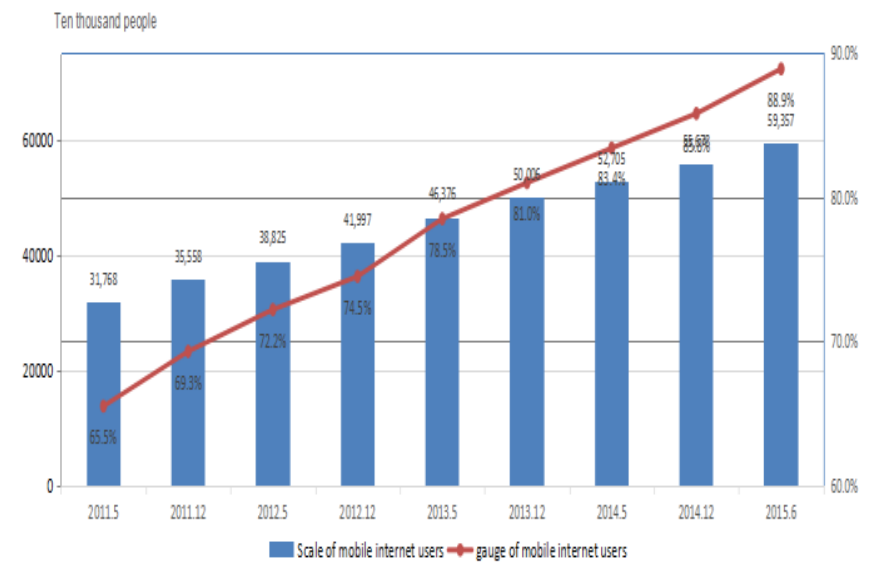

Figure 2. Chinese mobile Internet users scale and accounts for the proportion of Internet users

Source: China Internet network information center 


\section{E. The scale of online travel services continues to expand and emerging business models spring up}

The rapid development of information technology and tourism makes online travel service develop and the scale of the tourism industry expands quickly. Chinese market size exceeded 1 trillion, but the online travel is only 2.25 billion. While the U.S. online travel market amounted to $\$ 91$ billion,that is the total of 627 billion RMB. In 2007 China's online travel market accounted for about $3 \%$ of the overall tourism market and the international online travel accounts for about $25 \%$ to $30 \%$ of the overall tourism market. In 2008 travel booking users reached to 6 million people with marketing over 2.77 billion. In 2009, Chinese online travel booking users reached to 27.5 million, an increase of this year is also expected to reach million with an increase of 95\%. By 2013 that figure is expected to reach 168 million people. In 2009 China's online travel booking market scale is 3.89 billion yuan with an increase of $32.3 \%$. In 2010, that number is expected to get to 6.16 billion yuan with an increase of $58.4 \%$. In 2014, that number is expected to reach 24.56 billion yuan. CNNIC reports, until June 2010, the utilization rate of travel booking is $8.6 \%$ and the users are up to 36.12 million people. In December 2009, 30.24 million people of user scale grow $19.4 \%$. We can know that the time online travel services in our country is not long and the reserve ratio is relatively low, but growth trends speed up. At the same time, since the next year Ctrip.com is founded, then followed many tourism business model ,such as eLong, LY.com, lvmama.com, tuniu.com, Qunar, Kuxun, Youduoduo, Daodao.com,ect.On the other hand, Shanda, Taobao, Tencent and social media have also added to the online travel service industry, it is the emergence of a variety of business with varieties of descriptions and competition. Mixed mode shows online travel services in China's vast development can still develop better.And it will create many creative business models based on the Internet same as the tourism service[9], which represents that it not only has a broad space for development, but also has changed the tourism pattern and mode and in the future it will have a great impact on tourism.By now, under the double impact of information technology and consumer demand, the online travel service occurs a variety of business pattern. However,the research is still in the initial stage, That' $s$ why I write this paper that takes business model as the breakthrough point and systematically studies the business model of online travel service.

\section{BBASED ON THE DEVELOPMENT TREND OF BOTH INTERNET AND FUTURE TOURISM}

\section{A. Self-travel is the trend of the future.}

Now most of the young people are willing to take a trip with a backpack and a SLR at any time if they want to.With the improvement of living standards and the tourism industry, tourism has been of great importance and been taken good care of a lot than before, which creates a great deal of tourism masters. With rich experience, it's undoubtedly no problem for them to have a self-travel and make a schedule for the trip.

\section{B. The common tendency of high-end custom tourism scheme}

This kind of service have already existed in a number of travel agencies. And that' $\mathrm{s}$ why there is a creative mode named $\mathrm{C} 2 \mathrm{~B}$, which means customers to business (i.e., the customer decide what to buy and what price they require, then the merchants make the decision whether to accept the customer's requirements.) This service makes everything more convenient. For example, if they accept your price, and provide the service that you want, then the deal is finished. Normally, it's hard to get used to something new in a short time. Meanwhile, concerning to its high cost, only a minority of consumer can afford to this program, for which most of people would like to choose to travel with a group in agency. Therefore China's tourism industry has been caught in a passive position that cannot be break through. However it seems that it would be a perfect combination of new media and tourism industry which can change this impasse.

\section{One-stop service will become the main stream of online travelne-stop service will become mainstream online travel form}

As the continuous development of the market and consumer concept changed, the customer's tourism demand is more and more diversified, personalized, differentiated, and the change of product diversity and differentiation also has a higher demand, the change of customer demand will drive the industry chain and upgrade. Consumer booking travel products are gradually moving from line to online. To develop, including the integration of upstream and downstream tourism resources, and online travel service to improve the quality of service and the improvement of the booking experience also makes the old user's stickiness stronger. In addition to the convenience of online travel service, price transparency and other advantages, the Internet' s own characteristics will also attract more Internet users to collect, exchange information, and information exchange reservation service is an inevitable trend, and with China's e-commerce each link is gradually mature, select a network station service users will increase. Drive customer demand, mango net put forward a "one-stop" "supermarket" target. Mango from simple, single product sales of tourism elements to tourists as the center, a one-stop online travel supermarket direction to customer demand-oriented development. Because the customer demand is diversified. The product requirements also vary, so the mangocity.com positioning "one-stop" "supermarket" is to meet the customers' requirements of different products, to differentiation, personalized, customized products and services. The development direction of mango net platform, will meet the business travel, leisure travel groups and the needs of the mass market. Green mango Travel Network Mango, mango and ticket channel about on-line car rental business, will meet the continuous segments of the crowd, segments of the business and market demand segments. Online travel is a big trend in the development of the tourism 
industry, one-stop service for online travel and online travel trends[10].

\section{Travel plan website will become a hot spot}

With consumers highly demanding for personalized and experiential, online travel service, companies pay more attention to personalized and optional consumption experience. In the United Kingdom, the travel plan and coiasime.com had been founded and its beta search tools, Holiday Helper, lasted for several weeks for trial and everything went well. Therefore they decided to launch official version in January, 2010. They think: "this version is used for innovating online travel search and it will start a new age of personalized tourism for consumers." The plans are to launch a full-fledged version of search tools of Holiday Helper, through which users can save the search conditions, comments and filter search results and the use a lot of other new exciting functions. The headquarter in Menlo Park,California, Centr' D issued a notice to the U.S. Securities and Exchange Commission on December 24th that it has issued shares and raised nearly million dollars. Besides there are \$2.1 million in equity to be sold. The announcement did not specify the use of these funds. They use sontimontanalycis to pick up the users' reviews that the words are processed and then according to the user's personal preference to recommend restaurants, attractions, events and shopping choices. In the Atlantic and other parts of the world,they do produce a lot of innovative practice. I believe Chinese online travel service providers will also be added to the travel plans in the near future[11].

\section{E. Mobile online travel services will be the irresistible trend}

Frequent application activities on mobile phone sites are not only appearing in the retail industry but also experiencing the peak period.The latest research from Nielsen Co. shows that more and more consumers access to travel websites and applications through mobile phones to gain information, booking air tickets, hotels and car rental, ect, at anytime and anywhere. Besides, the possibility of the geographic location of the mobile device and free roaming fees, artificial environment technology and more of these technologies,all of these mean that the travel plans and reservations will move forward. Tourism activities on mobile devices, such as map view, the direction of navigation, local activities and tourism products and so on, gain momentum quicker than tourism trading. But as the source of tourism products trading, growth opportunities of mobile markets can not be ignored and are poised for any situation. The emergence of the mobile Internet brings change to travelers and online content in a interactive way. A survey shows that the an increase rate of the use of business travelers' mobile devices to get online travel information. Some similar situations are also reflecting on personal and wealthy travelers. Meanwhile Consumers also make use of their equipment to take part in more activities, including: travel research, travel reviews, check-in of the hotel, flight and cruise, and travel applications' download. Mobile devices will replace personal computers as well as become the user's Internet portal someday. So It is the field that is worthy of being concerned about.

\section{CONCLUSIONS}

Under the new economic situation, business model and innovation has become more and more important. With the dual incentive of online travel services and information technology developing, it makes travel service come true and arises at the historic moment and rapid expansion. Besides, business pattern emerges in diffrent ways and blooms in the near future.Combined with the Internet and tourism new model, it will be the new direction of the tourism development in the future.

\section{REFERENCES}

[1] Xu Xue, A brief discussion on the tourism business model and information service[J], Science and Technology Letters, 2008 (3), pp.56-62

[2] Hao Lin, Analysis of the new model of tourism group buying online marketing $[\mathrm{J}]$, the Journal of Liaoning Administration Institute, 2014 (8), pp67-72

[3] Zhao Ying, The problems and Countermeasures of tourism marketing[J], the Journal of Jilin Province Economic Management Cadre College, 2008 (4), pp89-94

[4] Yao Zhengguo, The development characteristics of China's sports tourism industry in the new period[J], Journal of Hubei University of Economics: Humanities and Social Sciences, 2014(13),pp234-236

[5] Li Dong, Zheng Xiangmin, Online travel services: concept analysis and pattern classification[D], Journal of Beijing International Studies University, 2011(12)

[6] Li Dong, Business model online travel service[D] , Huaqiao University Thesis, 2011(10),pp346-350

[7] Feng Wenjie, On the construction of the Boxing County tourism development planning and tourism management information system[D], Tianjin University Thesis, 2012(8),pp238-244

[8] Zhao Chunfeng, Strategic research of different tourism e-commerce website[D], Beijing University of Posts and Telecommunications Thesis 2013(6),pp181-187

[9] Ma Feng, Anhui construction research of public tourism service system[J], Anhui Universit y Thesis, 2012(7),pp93-97

[10] Wang Dongfeng, New observation about tourism: 4ages $\mathrm{x} 4$ directions[J], China's Urban Economy, 2011(9),pp167-172

[11] Wang Lepeng, Based on case analysis of online travel enterprise's leisure vacation product on strategy research[J], Commercial Economy, 2011(10),pp259-267. 